\title{
Marwan RASHED, La Jeune Fille et la Sphère. Études sur
} Empédocle

Paris, Presses de l'Université Paris-Sorbonne, 2018, "Philosophies", 300 p., ISBN : 979-10-231-0571-1

\section{Catherine Rowett}

\section{(2) OpenEdition}

12 Journals

\section{Electronic version}

URL: https://journals.openedition.org/philosant/4191

DOI: $10.4000 /$ philosant.4191

ISSN: 2648-2789

\section{Publisher}

Éditions Vrin

\section{Printed version}

Date of publication: 15 December 2021

Number of pages: $269-272$

ISBN: 978-2-7116-3036-3

ISSN: $1634-4561$

\section{Electronic reference}

Catherine Rowett, "Marwan rashed, La Jeune Fille et la Sphère. Études sur Empédocle", Philosophie antique [Online], 21 | 2021, Online since 03 April 2021, connection on 06 December 2022. URL: http:// journals.openedition.org/philosant/4191 ; DOI: https://doi.org/10.4000/philosant.4191

\section{(c) $\oplus \Theta \Theta$}

Creative Commons - Attribution-NonCommercial-NoDerivatives 4.0 International - CC BY-NC-ND 4.0 https://creativecommons.org/licenses/by-nc-nd/4.0/ 
néglige le sens de la « parabole » de Pythagore : c'est-à-dire pour maintenir l'hypothèse que tout au long du $\mathrm{V}^{\mathrm{e}}$ siècle av. J.-C., à la seule exception d'Héraclite, le sens de sophia reste limité à celui de la connaissance pratique mise en place dans des phrases morales, des conseils aux puissants et même l'engagement politique direct, sur le modèle des Sept Sages (cf. p. 96-104). Comme il l'écrit à la page 104 : « being sophos is a term for social engagement and problem-solving in a way that is publicly determined and applauded $\gg$. Au contraire, depuis le début du $\mathrm{V}^{\mathrm{e}}$ siècle, et pas seulement chez Héraclite, le sens du terme s'est élargi pour indiquer une connaissance qui se nourrit d'un regard sur la réalité des choses (theoria) avant de descendre (ou non) dans la praxis sociale et politique. Mais si l'on veut rechercher également dans le siècle précédent les signes d'une activité orientée avant tout vers la connaissance, on se souvient que l'engagement politique de Pythagore et de son école repose sur une vision préalable du cosmos et de l'âme dans laquelle la recherche scientifique est entrelacée avec un complexe de croyances et de pratiques religieuses. Platon se réfère à la portée totalisante d'une pensée théorique et morale, lorsqu'il attribue à Pythagore dans le dixième livre de la République (600b2-5) le fondement du bios Pythagorikos, c'est-à-dire d'un véritable « mode de vie » (hodos, tropos tou biou), qui en son temps est encore caractéristique des Pythagoriciens.

La construction de l'ensemble du livre souffre d'une tendance à la sur-interprétation, soutenue par une méthode « expansive », grâce à laquelle l'auteur peut extrapoler à partir des nombreux textes examinés des confirmations répétées de la centralité de l'aspect social et conversationnel de la philosophie. L'une des conséquences les plus évidentes de cette approche est que l'intérêt cosmologique qui appartient à la pensée grecque depuis ses débuts chez les Ioniens disparaît de l'horizon.

L'acuité interprétative de l'auteur donne des résultats bien plus convaincants lorsqu'elle s'exerce sur le terrain plus sûr des dialogues platoniciens ou des écrits d'Isocrate ou d'Aristote, non seulement parce que la documentation est plus étendue mais aussi parce que, entre-temps, la dimension dialectique de la philosophie a été mise en évidence grâce aux Sophistes et à Socrate. Mais l'impression est que toute la construction obéit, malgré les intentions initialement déclarées, à un préjugé sur « ce que c’est » que la philosophie. Ceci se révèle dans l'épilogue : «I suspect that there is nothing that "philosophy" (or philosophia) naturally or essentially or necessarily takes as its object, whether it is kosmos or being or self or thinking ... I think that philosophy is basically the practice of talking, with the goal of becoming a better person $\gg$ (p. 318). Bien sûr, la philosophie des premiers penseurs grecs était aussi ce que Moore y a cherché, mais pas uniquement. Pour comprendre les débuts de la philosophie grecque, caractérisée par une variété irréductible d'intérêts, de thèmes et de pratiques, il conviendrait de faire preuve de plus de prudence et d'une véritable et généreuse curiosité.

Maria Michela SAssi Università di Pisa

Marwan Rashed, La Jeune Fille et la Sphère. Études sur Empédocle, Paris, Presses de l'Université Paris-Sorbonne, 2018 (Philosophies), 300 p., ISBN : 979-10-2310571-1.

This book is an amazing treasure trove of riches, and my response, done properly, would probably occupy three monographs. Naturally, Rashed is addressing quite a few controversial issues concerning the interpretation of Empedocles, and on some of these I would heartily disagree with his conclusions, or have minor quibbles; but all his contributions are welcome and reflect a most impressive breadth of learning 
and scholarship. Where I disagree, it is mostly not that Rashed's reports of the textual evidence are faulty (although there are details in his emendations to the scholia, and to longstanding B fragments and testimonia that sometimes seem to be prompted by the preferred interpretation, not vice versa). My worries are more about the tramlines that Rashed is on: his adherence to certain existing patterns of interpretation, which bypass other lines that have been available for some time. And yet the book is also full of quite astonishing new suggestions that are nowhere on the existing tramline map for Empedocles - so perhaps (continuing the metaphor) I should say that Rashed has jumped on a populous tram, but driven it way off the tramway, to his own unexpected and somewhat strange destinations, way beyond the limits to which the passengers had previously ventured. Do we still find the real Empedocles in these weird destinations, or only a kind of fantasy? That is really quite hard to say: each reader will have to reach their own answer.

The book contains an introduction and seven chapters, divided into three Parts. Part 1 explores what is known as the "cosmic cycle" in Empedocles - that is, the alternating periods governed by love or strife. Chapter 1 focuses on the lengths of the periods in question, aiming to integrate and deploy the material that Rashed identified in some Byzantine scholia on Aristotle (scholia for which he is now well known, having published and discussed them in publications since 2001) and to whose validity he is now committed. Here he gathers his conclusions about the authenticity of the material as well as presenting his own reconstruction of Empedocles' cosmic cycle. Chapter 2 reworks an earlier article ('La zoogonie de la Haine selon Empédocle : retour sur l'ensemble ' $d$ ' du papyrus d'Akhmim', in Phronesis 2011): Rashed rejects some previous reconstructions of "ensemble d" in the papyrus (originally published in 1999 by Martin and Primavesi and subsequently discussed by various scholars including Janko and Primavesi). Rashed proposes several supplements and emendations to allow us "to understand Empedocles' argumentation with all its nuances" (86).

Chapter 3 offers a reconstruction of Empedocles fr. 38 (a quotation in Clement of Alexandria). Rashed challenges and rejects several testimonia (which he considers confused and mistaken) and substantially emends the text of the sole authority for the fragment itself. His claim is that (despite the ancient authorities) Empedocles really held a doctrine of two suns. He also gives a "poetic reading" of the fragment, invoking its echoes of the Iliad etc.

Part 2 investigates the "young girl" who features in Rashed's title and in Empedocles fr. 100 (the famous account of a child playing with a clepsydra - a device for holding and releasing water). Here Chapter 4 is a version in French of Rashed's 2007 paper 'The Structure of the Eye and Its Cosmological Function in Empedocles: Reconstruction of Fragment 84 D.-K.', in Reading Ancient Texts, vol. I, ed. Stern-Gillet and Corrigan, 21-39. It focuses on fr. 84, which is about the structure of the eye, but its link with the "jeune fille" lies the term koúp which means both the pupil of the eye and 'young girl'. This, Rashed suggests, is a reference to Persephone (Kore). Chapter 5 explores fr. 100 itself, again defending the thesis that the girl in the clepsydra fragment is Persephone, but also that the term "clepsydra" (hiding water) has links with Persephone, (witness the fountain called "clepsydra" on the North slope of the Athens acropolis). This chapter reworks Rashed's paper in Revue des Études Grecques, 121 (2008), 443-468.

In Part 3, Rashed turns to what he calls the Catharmes (i.e. the Katharmoi), assuming that fr. 115 is from the proem of a poem under that name (a view that I share) and that it was a separate work from the material treated in the rest of Rashed's book.

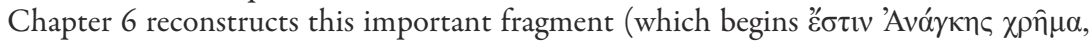




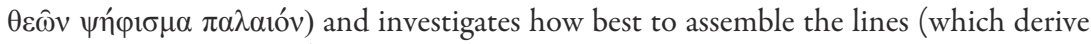
from various authorities). There are many good and useful observations here, alongside some that are controversial and deserve to be challenged-but the novel thesis (which then prompts the final chapter of Rashed's book) is that the proem is constructed in stanzas of eleven lines each, and that the number symbolism and the wandering "I" of the daimon are echoing the wanderings of Odysseus. Chapter 7 then suggests a link between Pythagorean cycles of ten, and a form of Homeric exegesis concerning the story of Odysseus, to propose a doctrine of a rebirth in the eleventh year, and wonders whether Empedocles' work is early evidence of Pythagorean allegorising of the Odyssey. Rashed then explores this theme in Apuleius' Metamorphoses, Hippolytus' account of the Naassenes, and a fascinating treatment of the number 11 in the architectural form of the Tabularium of Catulus at Rome (and the title epaphroditus taken by Sulla in the year 82).

I have written elsewhere of my scepticism about Rashed's reliance on the Byzantine scholia for reconstructing Empedocles' cosmic cycle, and also my scepticism about attempts to trace Pythagorean numerology in the cycle. I also have some doubts about the new ideas about the number 11 in Part 3 of Rashed's book. There are many things I could say about all these. I could also challenge the old assumption that the Katharmoi is not only a separate poem from the physics but also gets discussed last, in the old fashioned way: one of several ways in which Rashed seems to be riding an old tram driven by Denis O'Brien (much cited throughout Rashed's work). My own strong views on these matters don't dissolve on reading a single sentence of refutation in a footnote (e.g. p. 213 n. 2). Once, in chapter 1, on one specific issue in the cosmic cycle, Rashed notices a position that I offered, and correctly cites my view as similar to his own (notes 65 and 66 on pp. 76-77). I do indeed say, as he notes, that the oath in fr. 30 is not there to set a time for strife to return, but to specify a period during which it cannot return - though it would have been better to cite p. 288 of my later paper ('Sin and Moral Responsibility', 2003) where I give my own view, not 287 where I was reporting what I took to be a misunderstanding. Here (alone) Rashed does see that my view is not the standard one, but one that helpfully coincides, in some respects, with his own reconstruction.

On a related issue, however, I would have dearly liked to hear his response. Rashed rightly observes that Aristotle's comment about "equal times" in Physics VIII 1 is underdetermined and cannot justify interpretations like that of $\mathrm{O}^{\prime} \mathrm{Brien}$ (equal periods of unity and plurality). Rashed suggests that we should read it as a comment about internal symmetry within the period of movement. This is right, as is the observation that the "broad oath" of fr. 30 fixes the period of the Sphairos and nothing else. But now Rashed seems to say that all literal (i.e. not Neoplatonic) readers of the cycle derive the lengths of the other periods by extrapolating from the length of the Sphairos. I rejoiced to read, (p. 14), that we should not assume what the text does not say; for I share that opinion - and I am therefore a counter-example: not all literal readers define the cosmic periods by reference to the "broad oath". But if (as Rashed correctly notes) Aristotle means the equality of two matching periods within a cycle (increasing strife and increasing love) why should we assume (as Rashed seems to do) that those periods are always equal to their own repeat occasions in later or earlier cycles? Or, if we think that Aristotle does mean that they are equal from cycle to cycle, and wants that - a completely different issue - explained, then we should ask whether Aristotle was right, or had any reason to believe, that the durations were identical from cycle to cycle, and not just symmetrical in each cycle. I don't see Rashed asking this question, and he seems not to see that once you realise that the durations of each part of the cycle are not fixed by the oath, they need not 
be fixed by anything (or if they are fixed by something, we need to know by what). And then Aristotle is right, that nothing has been explained, if something makes them always equal but we are not told what.

To this puzzle, which underpins my own radically different proposal - that these periods are not set, nor need they be equal, from cycle to cycle, though they are always symmetrical and equal within a cycle - the Byzantine scholia offer no kind of solution. Rashed's scholia give inexplicable numbers that cannot answer Aristotle's question, whichever equality Aristotle was talking about. Producing some mystical numbers that add up to a multiple of 10,000 years is not providing a reason for that regularity, but merely asserting an arbitrary regularity, which strikes me as deeply unsatisfying. Why did Aristotle not discover Empedocles' properly satisfying answer to the questions about what sets the durations? Because, I would hazard, he looked primarily among the material to which we have conventionally attached the name "physics", and because in reality no answer to that question about durations can be supplied in physics, because the question about durations is (I think) not a question about what we think of as physics, and the basis for an answer is not to be found in the "physics" material. I suspect that is also why no one else, among those whom Rashed calls the "literal readers" of the cycle, could give an answer either, if they too (as Rashed does here) segregate the material related to ethics and the agency of daimones, and assign it to a separate story, in a separate poem called Katharmoi. This is where I differ from Rashed (as well as many others) who assume that the question about how long each section of the cosmic cycle lasts needs a mechanistic answer, rather than (as I would suggest) an ethical answer. That is, if the duration is variable, and is set by voluntary actions and their consequences, then the answers to "why?" and "how long?" have more to do with ethics than with the behaviour of inert elements.

Catherine RowetT

University of East Anglia, Norwich, UK

Platon, Ménexène, introduction, nouvelle traduction (texte grec en regard) et commentaire par Étienne Helmer, Paris, Vrin, 2019 (Les dialogues de Platon, 2), 183 p., ISBN : 978-2-7116-2826-1

Platon, Menexenus, edited by David Sansone, Cambridge, Cambridge University Press, 2020 (Cambridge Greek and Latin Classics), x +193 p. ISBN : 978-1-108-73056-3.

À l'instar de nombreux dialogues socratiques de Platon, le Ménexène s'ouvre sur une rencontre fortuite, près de l'agora, entre Socrate et le jeune Ménexène (qui est présent dans le Lysis et aussi dans le Phédon). Ils engagent une discussion à propos de l'éloge des soldats morts au combat traditionnellement prononcé lors de leurs funérailles publiques à Athènes, qui doivent bientôt avoir lieu et pour lesquelles l'orateur doit être choisi par le Conseil. Socrate estime que ce type de discours n'est pas difficile à composer et, face à la surprise de Ménexène, finit par proposer lui-même un exemple d'un tel éloge, qui aurait été écrit par Aspasie, auprès de qui Socrate dit apprendre la rhétorique, comme l'avait déjà fait Périclès. Suit l'oraison funèbre d'Aspasie-Socrate, qui occupe les quatre cinquièmes de ce court texte et qui suscite pour finir l'approbation et la reconnaissance de Ménexène... et le trouble ou le désintérêt de nombreux lecteurs de Platon, en particulier des philosophes, qui ont très peu fréquenté ce « dialogue ».

Les deux ouvrages recensés ici sont similaires par la taille, le public visé (plutôt des étudiants) et la structure (une introduction, le texte grec, un commentaire suivi, 